\section{STRATEGI KOMUNIKASI PARIWISATA OLEH DINAS PARIWISATA SUMATERA BARAT DALAM MENINGKATKAN BRAND IMAGE OBJEK WISATA DI SUMATERA BARAT}

\author{
${ }^{1}$ Defhany, ${ }^{2}$ Ria Edlina, ${ }^{3}$ Dion Eriend
}

1,2,3Program Studi Ilmu Komunikasi, Unversitas Dharma Andalas, Padang defhanydeva@gmail.com

\begin{abstract}
Abstrak
This study discusses the Tourism Communication Strategy by the West Sumatra Tourism Office in Improving the Brand Image of Tourism Objects in West Sumatra. The purpose of this research is to describe the things that become supporters and obstacles in the implementation of the tourism communication strategy by the West Sumatra Tourism Office in Increasing the Brand Image of Tourism Objects in West Sumatra. This is because there are still at least domestic tourists or foreign tourists visiting existing tourist objects. in West Sumatra, considering that many tourist objects in West Sumatra are not inferior to other provinces, this research can encourage the West Sumatra Tourism Office to improve the quality of tourist objects in the West Sumatera area. The research method used in this research is descriptive qualitative research conducted in 2019. The informants in this study consisted of 3 employees at the West Sumatra Tourism Office, namely Head of Marketing and Brand Strategies, head of Division Human Resources Development and Business Protection, and the Tourism Resources Development Section of the West Sumatra Provincial Tourism Office. Informants are determined by purposive sampling. The results of this study are, West Sumatra tourism communication strategy by promoting tourism using various social media such as Instagram and Facebook and optimizing the use of the West Sumatra Tourism Office website and through marketing and promotion of the advantages of tourism objects by involving various parties, such as the tourist business actors, investors, journalists from various media and visiting tourists. Always maintaining various interconnected tourism products, starting from cultural festival events, transportation to tourist objects, up-to-date information about tourist objects, tourism activities accompanied by promotions in various cities and the availability of communication media that are easy to find by tourists and a friendly communication culture with tourists visiting the tourist attraction.
\end{abstract}

Keywords: Communications Strategy, Communication Tourism, Brand Image, Tourism Destination, Provincy of Sumatera,

\section{PENDAHULUAN}

Salah satu faktor potensial yang dapat potensi wisata haruslah dilakukan lebih dikembangkan didaerah adalah sektor terukur dan sistimatis. Proses branding pariwisata sehingga proses identifikasi yang dilakukan oleh daerah merupakan 
sebuah strategi komunikasi yang kompleks sebab untuk menghasilkan brand yang kuat dan berkarakter diperlukan kajian mendalam sehingga mampu mengkomunikasikan keunggulankeunggulan daerah yang komparatif. Keputusan suatu daerah untuk melakukan city branding dapat dilihat sebagai suatu kebijakan komunikasi sekaligus kebijakan publik yang diambil oleh pemerintah daerah. Menyadari keunggulan dan daya saing saja tidak cukup, daerah harus mampu menciptakan citra atau reputasi. Oleh sebab itu city branding merupakan bagian yang inheren dalam pengembangan daya saing daerah. Daya saing daerah yang rendah seringkali berkaitan dengan kurangnya pengetahuan (awareness) investor maupun wisatawan terhadap potensi yang dimiliki oleh daerah tersebut. Oleh sebab itu banyak daerah kemudian menyadari pentingnya melakukan branding guna menjaring investor dan wisatawan sebanyak mungkin (Kamil,2017).

Data Kementrian Pariwisata tahun 2018 menunjukkan bahwa sejak 2013 sektor pariwisata menempati posisi empat setelah minyak dan gas bumi, batubara serta kelapa sawit sebagai penghasil devisa negara terbesar. Secara langsung, Presiden Joko Widodo juga telah memberikan arahan untuk memajukan 10 destinasi wisata nasional dan adanya keintegrasian antara promosi perdagangan, pariwisata, dan investasi. Pada tahun 2015, Kementerian Pariwisata telah menargetkan kunjungan wisatawan mancanegara ke Indonesia sebanyak 10 juta wisatawan mancanegara, tahun 2016 ditargetkan 12 juta, tahun 2017 ditargetkan 15 juta, sehingga pada tahun 2019 diharapkan dapat memenuhi target yang sudah ditetapkan, yaitu 20 juta kunjungan wisatawan.Peningkatan jumlah wisatawan mancanegara merupakan salah satu target mikro pencapaian strategis Kementerian Pariwisata tahun 2015 - 2019 (Sari,2017).

Sudah seharusnya para pemangku kepentingan pariwisata dapat menerapkan teknik dan strategi pemasaran pariwisata yang modern. Hal tersebut juga termasuk dalam saluran distribusi dengan memperhatikan media iklan yang sesuai dengan target pasar yang dijadikan sasaran. Pemasaran pariwisata menjadi salah satu komponen penting dalam pembangunan pariwisata. Sebab pembangunan pariwisata tersebut meliputi industri pariwisata, destinasi pariwisata, pemasaran, dan kelembagaan pariwisata. Pemasaran pariwisata bertujuan untuk mengupayakan agar sebuah destinasi atau produk pariwisata laku untuk dijual kepada 
konsumen sehingga tujuan pariwisata dalam hal ini untuk meningkatkan kesejahteraan masyarakat sekitar tercapai. Oleh karena itu, evolusi pemasaran pariwisata pun harus dilakukan. Evolusi pemasaran pariwisata yang dimaksud adalah dengan memanfaatkan kemajuan dan perkembangan teknologi terutama di bidang komunikasi.Pada era digital ini, informasi mengenai segala hal yang terjadi di berbagai belahan dunia ini bisa didapatkan dengan mudah. Hal tersebut tentunya bisa dimanfaatkan sebagai media untuk melakukan publikasi tentang pariwisata Indonesia terutama untuk promosi ke mancanegara (Sari. 2017)

Sayangnya persoalan yang kerap kali terjadi adalah pencitraan daerah seringkali terjebak sekedar pada aktivitas yang bersifat artifisial semata. Daerah hanya membuat jargon-jargon tetapi tidak disesuaikan dengan potensi dan karakteristik daerah. Jargon-jargon yang dibuat juga tidak diintegrasikan dan tidak representatif dengan masterplan pembangun daerah yang telah direncanakan, padahal kesesuaian antara citra yang diciptakan melalui jargonjargon daerah haruslah sesuai dengan rencana pembangunan daerah. Dengan menerapkan branding, sebuah kota mampu membangun identitas yang jelas, asosiasi yang kuat dan menyematkan atribut positif agar mampu menempatkan daerahnya dan memenangkan persaingan dengan daerah lain. Branding tempat dipercaya sebagai cara ampuh untuk membuat sebuah kota dapat dikenal, ini adalah paradigma cara baru mengenai bagaimana sebuah daerah harus dikelola dimasa yang akan datang (Kamal, 2017).

Mem-branding objek destinasi wisata dapat menggunakan nama, simbol, logo, desain, slogan, tagline, atau percampuran dari beberapa atau semua aspek tersebut agar semakin menarik wisatawan. Brand destinasi digunakan untuk memperkenalkan produk suatu destinasi wisata serta mengkomunikasikan keunikan destinasi tersebut secara visual, sehingga memudahkan destinasi untuk menjual produknya ke pasar pariwisata. Selain itu, Brand Destinasi memiliki arti yang tidak hanya sebatas slogan, tagline, logo destinasi, dan lainnya saja. Menurut Bungin (2015: 23), Brand suatu destinasi haruslah mencakup keseluruhan destinasi yang didalamnya terdapat nilai, filosofi, budaya, serta harapan masyarakat atau stakeholder di dalam destinasi tersebut.

Wakil Gubernur Sumatera Barat Nasrul Abit menyampaikan, potensi destinasi wisata halal Sumbar untuk 
menjadi yang terbaik di Indonesia sangat besar."Hari ini kita menyadari banyak hal yang mesti kita benahi bersama. Soal sertifikasi makanan halal bagi setiap restoran, pelayan hotel halal, serta memaksimalkan potensi tempat ibadah Masjid Raya Sumatera Barat lebih bermakna sebagai magnet perhatian di Padang," katanya. Untuk lebih maju dan meningkatkan kunjungan wisata, tentu butuh komitmen bersama-sama pemerintah dan stekholder melakukannya. Potensi besar Sumatera Barat dalam destinasi wisata tanpa dukungan dan kerja sama semua pihak tentu tidak akan berhasil dengan baik. Jika Sumbar mampu menumbuh kembangan destinasi wisata halal dengan baik, tentu kunjungan wisatawan mancanegara akan meningkat pula yang berdampak akan produktifitas masyarakat akan lebih baik dan sejahterah."Kita berharap satu saat destinasi wisata halal Sumbar dapat menjadi yang terbaik di Indonesia, karena itu bahagian dari proses kerjabersama untuk kemajuan daerah," ujarnya. (Zaranton, 2018)

\section{METODOLOGI PENELITIAN}

Komunikasi pariwisata pada prinsipnya merupakan suatu aktivitas manusia dalam menyampaikan informasi tentang
Belum jelasnya nama brand destinasi yang dimiliki oleh Provinsi Sumatera Barat membuat provinsi ini masih belum dikenal secara luas oleh wisatawan. Belum dioptimalkannya promosi yang dilakukan oleh Dinas Pariwisata Sumatera Barat, maka membuat banyaknya objek wisata yang belum terekspos dengan baik oleh media sehingga sangat disayangkan banyaknya objek wisata yang ada di Sumatera Barat belum bisa dikenal dengan baik oleh calon wisatawan. Hal ini harus menjadi perhatian serius bagi pemerintah daerah untuk lebih meningkatkan brand destinasi objek wisata dengan baik dengan cara komunikasi pariwisata.

Dari penjelasan tersebut, peneliti tertarik untuk meneliti mengenai strategi komunikasi pariwisata maka dari penjelasan ini mengangkat penelitian ini kedalam sebuah penelitian dengan judul Strategi Komunikasi Pariwisata Oleh Dinas Pariwisata Sumatera Barat Dalam Meningkatkan Brand Image Objek Wisata Di Sumatera Barat.

perjalanan ke suatu daerah /objek wisata yang akan dikunjungi wisatawan dengan menikmati perjalanan dari satu objek ke objek wisata lain sehingga wisatawan 
tertarikdan sampai pada tindakan untuk mengunjunginya. (Bungin, 2015 : 85)

Salah satu bidang dalam komunikasi pariwisata yang berhubungan dalam penelitian ini adalah komunikasi pemasaran pariwisata. (Tourism communication marketing/TCM) yakni mengkaji secara keseluruhan dalam konteks komunikasi pemasaran 4P (place, promotion. Destinasi pariwisata modern sangat kompleks dan sangat kapitalistik, dengan demikian pengelolaan pariwisata modern harus menggunakan manajemen bisnis yang akurat dan terukur. Dalam manajemen pariwisata modern seluruh hal ihwal pariwista harus dipetakan berdasarkan jenis usaha yang dapat dikelola dengan baik, sehingga manajemennya menjadi baik dan dapat dibangun koneksitas yang baik pula diantara jenis-jenis usaha pariwisata itu. Saat ini seluruh kompleksitas pariwisata dapat dikelompokkan berdasarkan komponen dan elemen penting. (Bungin:2015)

$$
\text { Pariwisata modern dapat }
$$
diklasifikasikan dalam beberapa komponen penting yaitu 1). destinasi, 2), transportasi, 3). pemasaran pariwisata, 4). sumber daya. dalam perspektif yang lain, pemerintah indonesia mengklasifikasikan komponen pariwisata ke dalam beberapa bagian penting seperti : 1). industri pariwisata, 2) destinasi, 3). pemasaran pariwisata, 4). kelembagaan pariwisata. Komponen dan elemen pariwisata ini akan terus berkembang sesuai dengan kreativitas stakeholder pariwisata di suatu daerah atau negara. Kemajuan teknologi informasi dan transportasi saat ini menyebabkan berbagai destinasi dapat berinteraksi dan dengan mudah saling bertukar pengalaman, sehingga perkembangan destinasi disesuaikan dengan kekuatan modal destinasi pariwisata. Hukum ekonomi berlaku dalam perkembangan destinasi. Data awal tentang jumlah kunjungan wisata, baik domestik maupun wisata mancanegara menjadi dasar dan alasan yang kuat masuknya modal investasi di destinasidestinasi berprospektif. (Bungin, 2015:86)

Metode yang digunakan dalam penelitian ini adalah pendekatan kualitatif. Menurut Sugiyono (2009: 8)mengatakan bahwa:"Metode penelitian kualitatif sering disebut metode penelitian naturalistik karena penelitiannya dilakukan pada kondisi yang alamiah (natural setting);disebut sebagai metode kualitatif, karena data yang terkumpul dan analisisnya lebih bersifat kualitatif". 


\section{HASIL DAN PEMBAHASAN}

Komunikasi pariwisata menjadi salah satu cara atau langkah dalam memperkenalkan berbagai macam potensi objek wisata daerah yang ada di Indonesia. Melihat banyak atau beragamnya potensi wisata daerah yang belum tersentuh oleh pemerintah daerah ataupun masyarakat dan wisatawan lokal dan wisatawan mancanegara. Mengingat banyak brand image objek wisata di berbagai daerah di Indonesia yang memiliki citra yang diunggulkan secara bersaing untuk mengembangkan berbagai objek wisata yang berpotensi bersaing demi keunikan, ciri khas objek wisata agar menjadi sorotan dari berbagai wisatawan.

Persoalan penting dari komunikasi pariwisata dari meningkatkan brand image objek wisata daerah adalah bagaimana strategi dalam menaikkan kualitas objek wisata daerah yang sangat berpotensi untuk dikenal dan dijajaki oleh wisatawan. Maka diperlukan strategi komunikasi pariwisata yang optimal dan terencana dengan baik oleh Dinas Pariwisata, agar citra dan reputasi objek wisata terkenal dan banyak wisatawan yang berkunjung sehingga pendapatan daerah meningkat dan membuka lapangan pekerjaan terbuka. Oleh karena itu diperlukan kerjasama bukan hanya dari pemerintah dan masyarakat setempat melainkan para pelaku usaha wisatawan, investor dan para wisatawan untuk meningkatkan reputasi objek wisata. Penyebab rendahnya reputasi objek wisata atau brand image objek wisata daerah dikarenakan kurangnya pengetahuan dan kepedulian yang belum tumbuh diantara mereka terhadap objek wisata. Oleh karena itu diperlukannya merek atau nama dari objek wisata daerah tersebut untuk meningkatkan potensi dan karakterisitik atau ciri khas objek wisata.

Karakteristik atau ciri khas objek wisata daerah dapat meningkatkan brand image objek wisata. Dalam wawancara dengan pihak dinas pariwisata provinsi Sumatera Barat yaitu dalam meningkatkan dan mengembangkan objek wisata daerah melalui pemasaran, dan promosi mengenai keunggulan objek wisata dengan melibatkan berbagai pihak, seperti para pelaku usaha wisatawan, investor, wartawan dari berbagai media dan para wisatawan yang berkunjung. Selalu mempertahankan berbagai produk wisata yang saling berhubungan yaitu selalu mempertahankan objek wisata mulai dari acara festival budaya, transportasi menuju objek wisata, informasi yang uptodate mengenai objek wisata, kegiatan wisata yang dibarengi promosi di berbagai kota 
dan tersedianya media komunikasi yang mudah di gapai oleh wisatawan serta budaya komunikasi yang ramah dengan wisatawan yang berkunjung ke objek wisata.

\section{Memiliki brand image Objek} Wisata yang dikenal di hati dan positioning wisatawan merupakan hasil dari perencanaan strategi dari komunikasi pariwisata yang baik sehingga memperoleh keunggulan dari produk wisata yang disesuaikan dengan keinginan dari wisatawan dan sumber daya yang ada. Strategi komunikasi pariwisata ini harus dilakukan mengingat jumlah kunjungan wisatawan yang harus meningkat untuk pemasukan pendapatan daerah. Hal ini tertuang dalam Peraturan Pemerintah No.50 Tahun 2011 tentang Rencana induk Pembangunan Kepariwisataan Nasional Tahun 2010 - 2025, pemasaran pariwisata adalah serangkaian proses untuk menciptakan, mengkomunikasikan, menyampaikan produk wisata dan mengelola relasi dengan wisatawan untuk mengembangkan kepariwisataan dan seluruh pemangku kepentingannya.

$$
\text { Realita yang terjadi dalam }
$$
menempatkan brand image objek wisata ini harus diperhatikan secara baik dan tersusun secara sistematis yang ditangani oleh beberapa pihak karena karena untuk keberlangsungan objek wisata daerah agar tetap eksis dan meningkat. Hal lain yang perlu menjadi perhatian dalam mengkomunikasikan pariwisata daerah adalah dnegan selalu mememperhatikan keinginan dari wisatawan terhadap apa yang mereka harapkan kedepannya mengenai objek wisata daerah. Seperti lokasi yang mudah dijangkau, keamanan wisatawan di daerah objek wisata, informasi yang jelas dan kualitas pelayanan pariwisata meliputi keamanan, kenyamanan, suasana privasi bagi wisatawan, rasa hormat, keramahan, santun dan jujur dari masyarakat di objek wisata menyambut wisatawan, daya tanggap masyarakat, sehingga akan ada kesan baik dari objek wisata tersebut di mata wisatawan yang berkunjung. sehingga strategi komunikasi pariwisata yang sudah dirancang untuk mencapai tujuan tersebut terlaksana walaupun belum maksimal dan optimal karena dalam hal ini masih membutuh waktu, uang dan kerjasama dari berbagai pihak untuk keberlanjutan dalam meningkatkan brand image objek wisata.

Berdasarkan hasil wawancara dengan Dinas Pariwisata Provinsi Sumatera Barat yaitu strategi komunikasi pariwisata Sumatera Barat dalam meningkatkan brand image objek wisata 
daerah dengan meningkatkan kualitas yang ada dari objek wisata daerah tersebut seperti bukti pelayanan yang baik kepada wisatawan mulai dari cepat tanggap terhadap kebutuhan wisatawan. Begitu juga dengan pernyataan Pak Riza Chandra di Dinas Pariwisata Sumatera Barat yang menyatakan bahwa komunikasi pariwisata dalam memperkenalkan objek wisata di Sumatera Barat dengan mengadakan beberapa kegiatan yaitu :

"kami juga mengadakan kegiatan Family Relations Trip yang dimana kami memfasilitasi travel agent,jurnalis, dan fotografer dari luar Sumatera Barat untuk datang ke Sumatera Barat. dan alhamdulilah sampai sekarang kami tetap melaksanakannya dan juga sudah ada hasilnya. Dan disamping itu kita juga melakukan kegiatan FAMTRIP.(FAMILI RELATIONS TRIP), kegiatan ini kami memfasilitasi travel agent dan jurnalis, fotografer dari luar Sumatera Barat untuk datang ke Sumatera Barat. Kami mengundang mereka untuk datang kesini. Kami faslitasi selama disini. Kami mengajak mereka survei di beberapa objek wisata di Sumatera Barat. Dan objek wisata ini sudah mereka lihat, dan kemudian mereka membuat draft atau paket tour di Sumatera Barat. Dan kemudian mereka menjual di daerah mereka. Kalo kolega kita travel agent".

Menurut penulis hal ini sangat disayangkan mengingat banyak beberapa objek wisata di Sumatera Barat yang menarik dan indah untuk dikunjungi oleh wisatawan, Namun kurangnya pengenalan dan promosi yang rutin melalui media oleh Dinas Pariwisata Sumatera Barat menjadikan kurangnya minat wisatawan untuk berkunjung dikarenakan kurangnya informasi yang didapatkan.

Minimnya pengenalan dan promosi yang rutin melalui media oleh Dinas Pariwisata Sumatera Barat tetap memiliki objek wisata yang masih tetap iconic seperti pernyataan Pak Riza Chandra yang menyatakan bahwa :

"kita memang mempunyai destinasi wisata yang menjadi icon, dan kita tidak bisa mengandalkan satu lokasi wisata saja. Karena kita berbicara di lingkup provinsi Sumatera Barat. Berdasarkan jumlah kunjungan wisatawan nusantara yang ke Sumatera Barat rata-rata memang di 3 kota seperti bukit tinggi, tanah datar, dan pesisir selatan yg terkenal dengan pantai corocok dan pulau mandehnya. 3 lokasi tersebutlah yang menyumbangkan destinasi wisata favorit di Sumatera Barat."

Maka dari itu perlunya strategi komunikasi pariwisata dengan mengenal siapa dulu komunikan yang akan dikenalkan mengenai objek wisata yang dipasarkan. Hal ini penting karena dengan mengenal profile wisatawan itu harus kita ketahui dulu baru bisa menjual produk yang ingin Dinas Pariwisata punya. Seperti yang diungkapkan oleh Pak Riza Chandra yang menyatakan bahwa :

"misalnya BukitTinggi dan BatuSangkar itu bisa kita pasarkan ke wisatawan Malaysia, karena mereka lebih suka shopping. Dan mengunjungi destinasi 
yang aktivitasnya tidak banyak. Berbeda dengan wisatawan asal eropa dan Australia, kita harus mengetahui dulu kemauan dari wisatawan itu seperti apa dan itu yang kita jual. Jadi bukan ini yang kita punya lalu kita jual. Dan inilah strategi khusus atau trik yang kita lakukan terhadap wisatawan. Seperti kemarin kita mengundang agensi dari Cina, kita pelajari karakteristik wisatawan Cina ini seperti apa dan ternyata wisatawan asal cina ini lebih suka di laut / bahari dan dipulau".

Membentuk brand image objek wisata suatu daerah harus memperhatikan beberapa hal yang berdasarkan pengamatan peneliti diantaranya ciri khas, karakteristik yang unik, gaya personalitas objek wisata yang dikemas menjadi pesan yang bisa membuat kesan menarik, mudah diingat oleh wisatawan dan munculnya rasa cinta untuk bisa kembali lagi ke objek wisata tersebut sehingga ingin selalu tinggal dalam jangka waktu lama. Namun hal tersebut membutuhkan tenaga, uang, keadaan yang saling mendukung dikarenakan membutuhkan waktu yang cukup lama dan komitmen yang kuat dan konsisten dari semua pihak yang ingin membentuk brand image yang baik di mata wisatawan dan masyarakat luas.

Semakin baik brand image objek wisata di mata wisatawan dan masyarakat akan berdampak pada meningkatnya citra objek wisata tersebut. Dengan memanfaatkan potensi daerah objek wisata yang dikemas dengan menarik agar bisa memiliki identitas objek wisata yang tampil beda dengan objek wisata lainnya. Dalam hal ini, Sumatera Barat memiliki banyak potensi yang besar, diantaranya keindahan alam seperti geopark yang ada dibeberapa lokasi di Provinsi Sumatera Barat, wisata alam dari tangan Sang Pencipta seperti beberapa wisata pantai, wisata budaya di setiap kabupaten yang memiliki ciri khas, wisata kuliner yang sudah terkenal di mancanegara seperti sate padang, rendang dan lainnya, wisata religi yang sudah terkenal seperti mesjid yang sudah ada sejak zaman penjajahan dan masih ada sampai sekarang yang dijaga keunikan dari mesjid tersebut, wisata edukasi seperti rumah para tokoh cendikiawan, dimana cendikiawan baik ulama agama dan tokoh nasional Indonesia rata-rata berasal dari Sumatera Barat, dan wisata lainnya yang masih butuh dikembangkan.

Strategi yang dilakukan dalam komunikasi pariwisata diantaranya dalah penentuan brand image objek wisata, segmentasi pasar, dan positioning. Dalam membangun dan mengembangkan brand image objek wisata daerah diperlukan usaha yang kuat dari para pemangku pelaku pariwisata yang dapat menerapkan 
teknik atau strategi komunikasi pariwisata yang baik dan modern. Hal ini harus memperhatikan saluran distribusi yaitu dengan memperhatikan media komuniaksi seperti iklan yang sesuai dengan target pasar yang dijadikan objek sasaran dari objek wisata daerah. Oleh karena itu, setiap objek wisata daerah membutuhkan brand image yang kuat dalam menghadapi tuntutan globalisasi saat ini yang berkembang sangat pesat, sehingga Pemerintah daerah harus menyadari pentingnya nilai dari brand image objek wisata daerah dalam membangun brand untuk wilayahnya berdasarkan potensi wisata daerah yang bisa membuat positioning yang menjadi target wilayah tersebut. Brand Image menjadi strategi komunikasi pariwisata lokal yang menjadi perhatian serius. Hal ini harus melakukan beberapa pendetailan dari nama atau ciri khas objek wisata daerah. sehingga memberikan referensi yang baik bagi wisatawan dalam mencari keunikan dari objek wisata yang disesuaikan dengan keinginan dari pasar wisatawan tersebut.

Menurut pengamatan penulis pentingnya keberadaan brand image dari objek wisata merupakan hal penting dikarenakan bisa memberikan persepsi dan representasi yang baik serta menumbuhkan kesadaran kepada wisatawan dan masyarakat bahwa objek wisata di daerah tersebut mendapatkan citra baik dan bisa diingat untuk bisa datang kembali ke objek wisata. Untuk memperoleh brand image objek wisata ini memang tidak mudah membutuhkan waktu dan tenaga yang cukup lama, asalkan adanya kemauan yang kuat untuk membentuknya. Namun menjadi perhatian bagi kita yang sadar akan pentingnya ukuran brand image ini untuk dimasa yang akan datang.

Tujuan adanya brand image objek wisata ini memberikan pemahaman kepada masyarakat dan wisatawan bahwa objek wisatadaerah ini memiliki spesifikasi yang berbeda dari objek wisata daerah yang lain. Kebutuhan dari segmentasi wisatawan yang beranekaragam dari berbagai tempat yang sudah dipenuhi keinginannya bisa juga memberikan brand image yang positif dikarenakan dapat membangun positioning di pikiran wisatawan itu cukup sulit dibutuhkan konsistensi, komitmen yang kuat diantara pelaku pariwisata dan pemerintah beserta masyarakat.

Baiknya brand image objek wisata daerah tergantung dari bagaimana komunikasi pariwisata yang dijalankan apakah berjalan sesuai dengan rencana yang matang atau tidak, sistem prosuder operasiona yang dilakukan sudah baik atau 
tidak, dan juga dibarengi dengan kenyataan yang ada dilapangan. Karena dengan adanya komunikasi yang baik akan memberikan sebuah harapan atau janji yang pastinya harus dilaksanakan. Jangan sampai harapan atau janji tersebut tidak terlaksana, sehingga akan menurunkan keandalan, keunikan dan citra dari objek wisata tersebut.

Hasil penelitan dan pengamatan yang penulis lakukan menunjukkan bahwa kendala atau hambatan dalam komunikasi pariwisata dalam meningkatkan brand image objek wisata yaitu mengalami beberapa hambatan diantaranya adalah minimnya sumber keuangan yang terbatas dalam menjalankan kegiatan komunikasi pariwisata untuk memperkenalkan objek wisata di daerah. Ini menjadi dasar utama kendala yang dihadapi, namun kendala yang lain juga tidak bisa dipungkiri dan dibantah seperti minimnya penggunaan media massa, sarana dan prasarana yang kurang memadai dan tidak terawat sehingga berdampak dalam memperkenalkan objek wisata.

Dinas Pariwisata Sumatera Barat harus menciptakan strategi komunikasi pariwisata yang baik dan efektif agar adanya kepedulian dan rasa memiliki di diri masyarakat dan pemerintah untuk melihat potensi dari beragam objek wisata di daerah. Karena akan membentuk adanya identitas dari produk pariwisata yang dimiliki. Namun, di Sumatera Barat hal ini masih sangat sedikit untuk menumbuhkan identitas dari produk pariwisata karena kurang adanya perhatian khusus dari pemerintah dan kerjasama dengan berbagai pihak untuk mengembangkan potensi objek wisata yang ada dibeberapa kabupaten di Sumatera Barat. Dibutuhkan kerja keras, komitmen dan kerjasama yang kuat antara masyarakat setempat objek wisata dan pemerintah daerah untuk mengembangkan potensi objek wisata diberbagai daerah di Sumatera Barat ini. sehingga pesan yang disampaikan kepada wisatawan belum didesain secara baik dan dengan memanfaatkan berbagai media saat ini agar pesan tentang objek wisata daerah dikenal oleh wisatawan. Hal ini menyebabkan belum meratanya informasi mengenai keanekaragaman objek wisata yang ada didaerah Sumatera Barat untuk dikenal oleh wisatawan.

Maka dari itu, diperlukannya peningkatan pelayanan fisik publik yang baik mulai dari fasilitas transportasi, kerahaman dan kesopanan masyarakat dalam menjamu wisatawan, masyarakat sudah peduli pentingnya branding objek wisata untuk meningkatkan jumlah wisatawan yang berkunjung ke objek 
wisata dalam rangka meningkatkan pendapatan daerah. Dinas Pariwisata Sumatera Barat juga berusaha dalam memperkenalkan berbagai budaya yang ada ke wisatawan seperti beragamnya wisata alam yang dimiliki mulai dari pegunungan, hutan, air terjun, sungai dan pantai, dikombinasikan dengan sejarahnya dan budaya yang kaya. Dan tak lupa pula wisatawan mendapatkan pengalaman yang menarik, seperti adanya tempat terbaik untuk berbelanja, di mana wisatawan dapat menemukan berbagai pilihan produk baik itu pakaian, souvenir, makan dan minuman tradisional yang halal, enak dan murah dan mendapatkan pelayanan dengan harga yang wajar.

\section{PENUTUP}

Berdasarkan hasil penelitian ini, penulis menarik kesimpulan diantaranya yaitu :

$\begin{array}{ccc}\text { Brand image objek wisata } \\ \text { merupakan } & \text { usaha } & \text { untuk }\end{array}$
mengkomunikasikan objek pariwisata dalam memperkenalkan tempat yang berbeda dari objek wisata lainnya dengan keunikan dan kekhasan yang dimilikinya. Maka dari itu, perlunya kegiatan komunikasi pariwisata dalam memperkenalkan brand image objek wisata dengan komunikasi yang baik, operasional yang baik, dan didukung
Dalam menerapkan brand image yang diinginkan oleh masyarakat dan Dinas Pariwisata Sumatera Barat perlu mengkomunikasikan seperti apa kenyataan dari brand image objek wisata dari beragam potensi daerah dari objek wisata tersebut. Hal ini berdampak dari nilai yang dirasakan oleh wisatawan terhadap brand objek wisata yang dijanjikan oleh Dinas Pariwisata. Maka dari itu, perlunya kampanye dari komunikasi pariwisata yang memiliki slogan dan nama yang mencirikan kekhasan dari objek wisata tersebut yang dapat menjadi identitas objek wisata.

oleh kenyataan secara fisik yang sesuai dengan melibatkan pemerintah daerah, masyarakat, para pelaku usaha pariwisata dalam memberikan rasa dan nilai brand image yang dijanjikan kepada wisatawan.

Semakin baik brand image objek wisata di mata wisatawan dan masyarakat akan berdampak pada meningkatnya citra objek wisata tersebut.Dengan memanfaatkan potensi daerah objek wisata yang dikemas dengan menarik agar bisa memiliki identitas objek wisata yang tampil beda dengan objek wisata lainnya. Dalam hal ini, Sumatera Barat memiliki 
banyak potensi yang besar, diantaranya keindahan alam seperti geopark yang ada dibeberapa lokasi di Provinsi Sumatera Barat, wisata alam dari tangan Sang Pencipta seperti beberapa wisata pantai, wisata budaya di setiap kabupaten yang memiliki ciri khas, wisata kuliner yang sudah terkenal di mancanegara seperti sate padang, rendang dan lainnya, wisata religi yang sudah terkenal seperti mesjid yang sudah ada sejak zaman penjajahan dan masih ada sampai sekarang yang dijaga keunikan dari mesjid tersebut, wisata edukasi seperti rumah para tokoh cendikiawan, dimana cendikiawan baik ulama agama dan tokoh nasional Indonesia rata-rata berasal dari Sumatera Barat, dan wisata lainnya yang masih butuh dikembangkan.

Hasil penelitan dan pengamatan menunjukkan bahwa kendala atau hambatan dalam komunikasi pariwisata dalam meningkatkan brand image objek wisata yaitu mengalami beberapa hambatan diantaranya adalah minimnya sumber keuangan yang terbatas dalam menjalankan kegiatan komunikasi pariwisata untuk memperkenalkan objek wisata di daerah. Ini menjadi dasar utama kendala yang dihadapi, namun kendala yang lain juga tidak bisa dipungkiri dan dibantah seperti minimnya penggunaan media massa, sarana dan prasarana yang kurang memadai dan tidak terawat sehingga berdampak dalam memperkenalkan objek wisata.

Berdasarkan hasil penelitian ini, penulis memberikan saran yang membangun untuk penelitian selanjutnya dan kepada beberapa pihak diantaranya yaitu :

Dalam keanekaragaman budaya dan objek wisata yang ditawarkan kepada wisatawan harus memiliki strategi atau cara yang komunikatif agar wisatawan dapat merasakan dan menilai keunikan atau kekhasan dari objek wisata yang ditawarkan, bisa memberikan semangat dan gairah untuk kembali lagi datang ke objek wisata tersebut. Serta yang menjadi juga perhatian adalah harus memberikan kenyamanan bagi wisatawan seperti fasilitas sarana dan prasanara yang baik bagi wisatawan yang berkujung dan informasi yang disediakan diberbagai media informasi yang mudah diakses oleh wisatawan dan selalu memberikan kenyamanan baik dari segi keramahtamahan masyarakat dalam menyambut wisatawan dan kesopanan masyarakat untuk bisa wisatawan merasa aman dan tenang di objek wisata yang dikunjungi.

Dinas Pariwisata Sumatera Barat harus menciptakan strategi komunikasi 
pariwisata yang baik dan efektif agar adanya kepedulian dan rasa memiliki di diri masyarakat dan pemerintah untuk melihat potensi dari beragam objek wisata di daerah. Karena akan membentuk adanya identitas dari produk pariwisata yang dimiliki.Dibutuhkan kerja keras, komitmen dan kerjasama yang kuat antara masyarakat setempat objek wisata dan pemerintah daerah untuk mengembangkan potensi objek wisata diberbagai daerah di Sumatera Barat ini. sehingga pesan yang disampaikan kepada wisatawan belum didesain secara baik dan dengan memanfaatkan berbagai media saat ini agar pesan tentang objek wisata daerah dikenal oleh wisatawan.

\section{DAFTAR PUSTAKA}

Bungin, Burhan. 2015. Komunikasi Pariwisata. Prenada media Group. Jakarta.

Freddy Handoko Istanto, Yohanes Somawiharja, dkk. Universitas Tarumanagara, Jakarta, 27 Oktober 2016 ISSN NO: $2541-3400$. Pengembangan Potensi Wisata Berbasis Brand Destination (Studi Kasus Destinasi Wisata Budaya Di Trowulan).

Ghifari Yuristiadhi \& Shintya Dewi Lupita Sari. 2017. Vol. 2, No. 2, Desember 2017. Strategi Branding Pariwisata Indonesia Untuk Pemasaran Mancanegara. ETTISAL, Journal of Communication. P-ISSN: 2503 EISSN: 2599-3240.
Jesi Indriani, C. K.2017. Pengaruh City Branding Pada City Image Dan Keputusan Berkunjung Wisatawan Ke. Manajemen, 17(November), 41-52..

Sadat, Andi M. 2009. Brand Belief : Strategi Membangun Merek Berbasis Keyakinan.Jakarta : Salemba Empat..

\section{SITTI UTAMI REZKIAWATY} KAMIL.2017. City Branding Sebagai Strategi Komunikasi Pariwisata Kabupaten Buton Tengah. Meta Communication; Journal Of Communication Studies Vol 2 No 1 Maret 2017P-ISSN : 2356-4490 EISSN : 2549-693X.

Sugiyono. 2009. Metode Penelitian Pendidikan (pendekatan kualitatif, kuantitatif, dan $R \& D)$ ). Bandung: Alfabeta.

Yunaini, Hani. 2017. Strategi Komunikasi Pariwisata Provinsi Maluku Utara pada Event Widi International Fishing Tournamen(WIFT) 2017. ISSN 26140829. Vol 1, No 1, Desember 2017.

Zar-Anton.2018. Antara Sumatera Barat.(https://sumbar.antaranews.com/ berita/237952/destinasi-wisata-halalsumbar-belum-tembus-tiga-terbaik) diakses tanggal 21 maret 2019 hari kamis pukul 10.43. 